\title{
Family history and risk of ductal carcinoma in situ and triple negative breast cancer in a Han Chinese population: a case-control study
}

Wenbin Zhou ${ }^{1 \dagger}$, Hong Pan ${ }^{1 \dagger}$, Mengdi Liang ${ }^{1 \dagger}$, Kai Xia $^{1,2}$, Xiuqing Liang ${ }^{1}$, Jinqiu Xue ${ }^{1}$, Lin Cheng ${ }^{1}$, Jialei Xue ${ }^{1}$, Si Chen'1, Xiaoan Liu', Qiang Ding', Lijun Ling ${ }^{1}$ and Shui Wang ${ }^{1 *}$

\begin{abstract}
Background: The association between family history and risk of triple negative breast cancer and ductal carcinoma in situ (DCIS) has not been well investigated, especially in Asian populations. We investigated the association between family history and risk of DCIS or triple negative breast cancer in a Han Chinese population.

Methods: A case-control study, comprising 926 breast cancer patients and 1,187 benign breast disease controls, was conducted in our hospital. Multivariate logistic regression was used to assess the relationships between family history and risk of DCIS or triple negative breast cancer.

Results: Subjects with a family history of breast cancer had higher breast cancer risk than those without a family history (odds ratio $(\mathrm{OR})=2.11,95 \%$ confidence interval $(\mathrm{Cl})=1.26$ to 3.52). Family history was not significantly associated with an increased risk of DCIS ( $\mathrm{OR}=1.27,95 \% \mathrm{Cl}=0.36$ to 4.46$)$, while family history was significantly associated with an increased risk of invasive breast cancer $(\mathrm{OR}=2.22,95 \% \mathrm{Cl}=1.32$ to 3.75$)$, irrespective of triple negative breast cancer $(\mathrm{OR}=3.35,95 \% \mathrm{Cl}=1.43$ to 7.88$)$ or non-triple negative breast cancer $(\mathrm{OR}=2.14,95 \% \mathrm{Cl}=1.21$ to 3.80$)$.

Conclusion: Our results indicate that having a family history of breast cancer is associated with an increased risk of triple negative breast cancer with a magnitude of association similar to that for non-triple negative breast cancer. Furthermore, family history is not significantly associated with an increased risk of DCIS. Future cohort studies with larger sample sizes are still needed to explore these relationships.
\end{abstract}

Keywords: Case-control, Ductal carcinoma in situ, Family history, Triple negative breast cancer

\section{Background}

Breast cancer is a worldwide malignant disease, and it is the leading cause of cancer-related death in women $[1,2]$. There is plentiful evidence to indicate that breast cancer is an epidemiologically, biologically, and clinically heterogeneous disease [3]. A special subgroup of patients is associated with aggressive clinical behavior and poor outcome [4-6]. This subgroup of breast cancer is characterized by absent expression of estrogen receptor (ER), progesterone receptor (PR) and HER2 receptor and is defined as triple negative breast cancer.

\footnotetext{
* Correspondence: ws0801@hotmail.com

${ }^{\dagger}$ Equal contributors

'Department of Breast Surgery, The First Affiliated Hospital with Nanjing Medical University, 300 Guangzhou Road, Nanjing 210029, China

Full list of author information is available at the end of the article
}

To the authors' knowledge, few risk factors for this breast cancer subtype have been identified. Family history is a key risk factor of breast cancer [7-12]. However, the association between family history and risk of triple negative breast cancer has not been well investigated. Some studies suggest that there is no difference in the prevalence of family history between women with triple negative breast cancer (or basal-like breast cancer) and other types of breast cancer [3,13]. By contrast, another previous study [14] suggests that a family history was associated with an increased risk of basal-like breast cancer. Furthermore, Jiang and colleagues observed an increased proportion of ER and PR negative breast cancer among younger Spanish women with a family history of breast cancer [15]. Therefore, the relationship between family history and risk of triple negative breast cancer is still not clear.

\section{Biomed Central}

(c) 2013 Zhou et al.; licensee BioMed Central Ltd. This is an open access article distributed under the terms of the Creative Commons Attribution License (http://creativecommons.org/licenses/by/2.0), which permits unrestricted use, distribution, and reproduction in any medium, provided the original work is properly cited. 
The incidence and mortality of breast cancer are significantly affected by racial or ethnic difference [15-19]. For example, previous studies suggested that Hispanic women had a lower rate of breast cancer than non-Hispanic white women, while Hispanic breast cancer patients were more likely to die of breast cancer than non-Hispanic white patients $[15,20]$. Furthermore, about $20 \%$ of Hispanic invasive breast cancer patients had a family history [15], while the proportion of breast cancer patients with a family history was only about $6.6 \%$ in a cross-sectional survey in China [1]. Up to now, there are limited amounts of data on the association between family history and triple negative breast cancer risk in Asian populations. Furthermore, there is little data on the relationship between family history and risk of ductal carcinoma in situ (DCIS) [21-25]. However, there is no data on the association between family history and risk of DCIS in Asian populations.

The aim of this study was to investigate the association between family history and risk of DCIS or triple negative breast cancer in a Han Chinese population. To our knowledge, this case-control study represents one of the first studies to determine these relationships in a large population of Chinese women.

\section{Methods}

\section{Ethics}

The study was approved by the ethics committee of the First Affiliated Hospital with Nanjing Medical University, and was performed in compliance with the Helsinki Declaration. All patients provided written informed consent for their clinical data to be reviewed by us.

\section{Study population}

Women with histologically confirmed breast cancers, on whom surgeries were performed by one group of surgeons in the First Affiliated Hospital with Nanjing Medical University from May 2005 to July 2012 were recruited as the case group. All subjects in this study were diagnosed with incident breast cancer, and were recruited without restriction of age or histological type. The patients were ethnic Han Chinese coming from different families. Patients with previous cancer history, metastasized cancer from other organs, and previous chemotherapy or radiotherapy were excluded. A control group of subjects with histologically confirmed benign breast disease, on whom surgeries were performed by the same group of surgeons in the same period, was also recruited. Both groups of patients were recruited without restriction of age, and were all ethnic Han Chinese, from different families without previous cancer history.

\section{Data collection}

The database of breast disease (breast cancer and benign breast disease) in our hospital was reviewed. Family history was defined as a history of breast cancer in any first-degree or second-degree relative [15]. Risk factors and clinical information were collected from medical records by trained physicians. The following selected risk factors were extracted if available: age at diagnosis, age at menarche, previous childbearing history, and family history of breast cancer. The following clinicopathologic variables were selected: pathology, tumor size, number of positive lymph nodes, ER status, PR status, and HER2 status.

\section{Pathology}

For histopathological examinations, the specimens were paraffin-embedded. Then, $4 \mu \mathrm{m}$ histological sections were cut and stained with $\mathrm{H}$ \& E. Immunohistochemical analyses on paraffin-embedded material were used to determine the ER and PR status, as described previously [26]. HER2 status was determined according to the American Society of Clinical Oncology guidelines [27]. DCIS with microinvasion $\leq 1 \mathrm{~mm}$ was used as the DCIS category. All patients with invasive breast cancer in this study were categorized into two subgroups: triple negative and non-triple negative. Either or both of ER and PR positive were considered hormone receptor positive, while both ER and PR negative were considered hormone receptor negative. Triple negative breast cancer was defined as ER, PR, and HER2 all negative. The pathology for both case and control groups was reviewed independently by an experienced pathologist.

\section{Statistical analysis}

Percentiles were used to analyze for numerical variables, and mean \pm standard deviation (SD) was also used to report the numerical data. Student's $t$ test was applied to identify the difference of mean age between the case and control groups. The chi-square test was applied to examine the differences for unordered categorical variables between the case and control groups, while the nonparametric rank test was applied to examine the differences for ordinal categorical variables between the two groups. Multivariate logistic regression analyses were performed to identify risk factors of breast cancer and subtype-specific breast cancer. The candidate explanatory variables in the multivariate logistic regression analysis were: age at diagnosis, age at menarche, previous childbearing history, and family history of breast cancer. Importantly, those with a family history of breast cancer are often diagnosed much younger than those without a family history. Age at diagnosis can therefore be an intermediate between family history and the occurrence of breast cancer. Adjusting for a disease intermediate can result in bias away from the null. So we also ran these analyses without age at diagnosis to see how much this affected the odds ratio (OR). Age at diagnosis in this study was categorized into seven subgroups: $\leq 30$, 31 to 40,41 to 50,51 to 60,61 to 70,71 to 80 , and $\geq 81$. Age at menarche was categorized into three subgroups: 
$\leq 13,14$ to 16 , and $\geq 17$. The number of children carried in this study was categorized into four subgroups: 0,1 , 2 , and $\geq 3$. Odds ratios and $95 \%$ confidence interval (CI) were used to assess breast cancer risk of candidate explanatory variables. All statistical analyses were performed using Stata version 11.0 (StataCorp, College Station, Texas). All tests were two-sided and a level of significance of 0.05 was applied.

\section{Results}

A total of 926 women with breast cancer and 1,187 women with benign breast disease were studied. The selected characteristics for breast cancer patients and control subjects are presented in Table 1 . The mean age of the control group $(44.8 \pm 12.5)$ was younger than that of the case group $(52.2 \pm 12.2)(P<0.001)$. Age at menarche was not well balanced between these two groups $(P<0.001)$. Furthermore, more patients in the case group had two or more children (30.6\%) than in the control group $(19.4 \%)(P<0.001)$; this was in accordance with the age distribution between the two groups. In this study population, $5.1 \%$ of breast cancer patients had a family history of breast cancer, which was higher than that in control group $(3.2 \%)(P=0.012)$.

Table 1 Distribution of selected variables between breast cancer patients and control subjects

\begin{tabular}{|c|c|c|c|c|c|}
\hline \multirow[t]{2}{*}{ Variable } & \multicolumn{2}{|c|}{$\begin{array}{c}\text { Cases } \\
(n=926)\end{array}$} & \multicolumn{2}{|c|}{$\begin{array}{c}\text { Controls } \\
(n=1,187)\end{array}$} & \multirow[t]{2}{*}{$P^{a}$} \\
\hline & $N$ & $\%$ & $N$ & $\%$ & \\
\hline Age at diagnosis (mean $\pm S D$ ), years & \multicolumn{2}{|c|}{$52.2 \pm 12.2$} & \multicolumn{2}{|c|}{$44.8 \pm 12.5$} & $<0.001$ \\
\hline$\leq 50$ & 453 & 48.9 & 819 & 69.0 & $<0.001$ \\
\hline$>50$ & 473 & 51.1 & 368 & 31.0 & \\
\hline \multicolumn{6}{|l|}{ Age at menarche, years } \\
\hline$\leq 13$ & 144 & 15.6 & 229 & 19.3 & $<0.001$ \\
\hline 14 to 16 & 406 & 43.8 & 643 & 54.2 & \\
\hline$\geq 17$ & 138 & 14.9 & 114 & 9.6 & \\
\hline Not available & 238 & 25.7 & 201 & 16.9 & \\
\hline \multicolumn{6}{|l|}{ Childbearing history } \\
\hline 0 children & 26 & 2.8 & 132 & 11.1 & $<0.001$ \\
\hline 1 child & 456 & 49.2 & 707 & 59.6 & \\
\hline 2 children & 191 & 20.6 & 162 & 13.6 & \\
\hline$\geq 3$ children & 93 & 10.0 & 69 & 5.8 & \\
\hline Not available & 160 & 17.3 & 117 & 9.9 & \\
\hline \multicolumn{6}{|l|}{ Family history } \\
\hline Yes & 47 & 5.1 & 38 & 3.2 & 0.012 \\
\hline No & 814 & 87.9 & 1143 & 96.3 & \\
\hline Not available & 65 & 7.0 & 6 & 0.5 & \\
\hline
\end{tabular}

${ }^{a}$ Student's $t$ test for age distribution between case and control groups; chisquare test for family history distribution between case and control groups; nonparametric rank test for other variables distribution between case and control groups.

\section{Multivariate analysis of breast cancer risk}

In multivariate logistic analyses (Table 2), age at menarche (all $P>0.1$ ) and previous childbearing history (all $P>0.1$ ) were not significantly associated with an increased or decreased breast cancer risk when other variables were adjusted. Compared with subjects younger than 30 years, increased age was significantly associated with increased breast cancer risk in all age subgroups (31 to $40 \mathrm{y}$ : OR = $6.14,95 \% \mathrm{CI}=2.58$ to $14.64 ; 41$ to $50 \mathrm{y}: \mathrm{OR}=10.31,95 \%$ $\mathrm{CI}=4.34$ to $24.51 ; 51$ to $60 \mathrm{y}: \mathrm{OR}=14.46,95 \% \mathrm{CI}=6.02$ to $34.69 ; 61$ to $70 \mathrm{y}$ : $\mathrm{OR}=16.08,95 \% \mathrm{CI}=6.41$ to 40.33 ; 71 to $80 \mathrm{y}: \mathrm{OR}=31.12,95 \% \mathrm{CI}=11.69$ to 82.89 ; $\geq 81 \mathrm{y}$ : $\mathrm{OR}=38.86,95 \% \mathrm{CI}=6.30$ to 239.57$)$. When other variables were adjusted, subjects with a breast cancer family history had a higher breast cancer risk than subjects without a family history $(\mathrm{OR}=2.11,95 \% \mathrm{CI}=1.26$ to 3.52 , $P=0.004)$. Similar results were obtained $(\mathrm{OR}=2.15,95 \%$ $\mathrm{CI}=1.31$ to $3.53, P=0.003)$ when multivariate analysis was performed without age at diagnosis.

\section{Comparison between triple negative and non-triple negative breast cancer}

Of 926 breast cancer patients in this study, 123 patients were diagnosed with DCIS, and 803 were diagnosed with invasive cancer. Of these 803 invasive cancer patients,

Table 2 Multivariate logistic analysis of breast cancer-related factors compared with benign breast disease control

\begin{tabular}{|c|c|c|c|}
\hline Variable & OR & $95 \% \mathrm{Cl}$ & $P$ \\
\hline \multicolumn{4}{|c|}{ Age at diagnosis, years } \\
\hline$\leq 30$ & Reference & & \\
\hline 31 to 40 & 6.14 & 2.58 to 14.64 & $<0.001$ \\
\hline 41 to 50 & 10.31 & 4.34 to 24.51 & $<0.001$ \\
\hline 51 to 60 & 14.46 & 6.02 to 34.69 & $<0.001$ \\
\hline 61 to 70 & 16.08 & 6.41 to 40.33 & $<0.001$ \\
\hline 71 to 80 & 31.12 & 11.69 to 82.89 & $<0.001$ \\
\hline$\geq 81$ & 38.86 & 6.30 to 239.57 & $<0.001$ \\
\hline \multicolumn{4}{|c|}{ Age at menarche, years } \\
\hline$\leq 13$ & Reference & & \\
\hline 14 to 16 & 0.83 & 0.63 to 1.09 & 0.172 \\
\hline$\geq 17$ & 1.21 & 0.84 to 1.74 & 0.309 \\
\hline \multicolumn{4}{|c|}{ Childbearing } \\
\hline 0 & Reference & & \\
\hline 1 & 1.24 & 0.71 to 2.16 & 0.448 \\
\hline 2 & 1.52 & 0.84 to 2.76 & 0.170 \\
\hline$\geq 3$ & 1.47 & 0.75 to 2.89 & 0.226 \\
\hline \multicolumn{4}{|c|}{ Family history } \\
\hline No & Reference & & \\
\hline Yes & 2.11 & 1.26 to 3.52 & 0.004 \\
\hline
\end{tabular}


ER, PR and HER2 status were all available in 706 patients, including 129 triple negative breast cancer patients, and 577 non-triple negative breast cancer patients. The distribution of selected variables between triple negative and non-triple negative breast cancer patients is shown in Table 3. Age at diagnosis $(P=0.354)$, age at menarche $(P=0.494)$, and previous childbearing history $(P=0.934)$ were not significantly different between triple negative and non-triple negative patients. Furthermore, tumor size between the two groups was not significantly different $(P=0.792)$. Like our previous study [26], triple negative breast cancer (34.88\%) had less lymph node involvement than non-triple negative breast cancer $(50.26 \%)(P=0.001)$. Importantly, the proportions of patients with a family history between the two groups were not significantly different $(P=0.599)$.

\section{Multivariate subgroup analysis of breast cancer risk in relation to family history}

Details of the multivariate subgroup analyses of breast cancer risk in relation to family history are shown in Table 4. Compared with benign breast disease control, family history was not significantly associated with an increased risk of DCIS ( $\mathrm{OR}=1.27,95 \% \mathrm{CI}=0.36$ to 4.46 , $P=0.704$ ), while family history was significantly associated with an increased risk of invasive breast cancer $(\mathrm{OR}=$ $2.22,95 \% \mathrm{CI}=1.32$ to $3.75, P=0.003)$ in our study.

In 803 invasive breast cancer patients, subgroup analyses regarding to tumor size, lymph node involvement, hormone receptor status, and molecular subtype were performed. When breast cancers were divided into two groups according to tumor size, family history of breast cancer was significantly associated with an increased risk

Table 3 Distribution of selected variables between triple negative and non-triple negative breast cancer patients

\begin{tabular}{|c|c|c|c|c|c|}
\hline \multirow[t]{2}{*}{ Variable } & \multicolumn{2}{|c|}{ Triple negative $(n=129)$} & \multicolumn{2}{|c|}{ Non-triple negative $(n=577)$} & \multirow[t]{2}{*}{$P^{a}$} \\
\hline & $N$ & $\%$ & $N$ & $\%$ & \\
\hline \multicolumn{6}{|c|}{ Age at diagnosis, years } \\
\hline$\leq 50$ & 61 & 47.29 & 247 & 42.81 & 0.354 \\
\hline$>50$ & 68 & 52.71 & 330 & 57.19 & \\
\hline \multicolumn{6}{|c|}{ Age at menarche, years } \\
\hline$\leq 13$ & 22 & 17.05 & 95 & 16.46 & 0.494 \\
\hline 14 to 16 & 57 & 44.19 & 256 & 44.37 & \\
\hline$\geq 17$ & 18 & 13.95 & 99 & 17.16 & \\
\hline Not available & 32 & 24.81 & 127 & 22.01 & \\
\hline \multicolumn{6}{|c|}{ Childbearing history } \\
\hline 0 children & 4 & 3.10 & 17 & 2.95 & 0.934 \\
\hline 1 child & 62 & 48.06 & 288 & 49.91 & \\
\hline 2 children & 28 & 21.71 & 117 & 20.28 & \\
\hline$\geq 3$ children & 12 & 9.30 & 64 & 11.09 & \\
\hline Not available & 23 & 17.83 & 91 & 15.77 & \\
\hline \multicolumn{6}{|l|}{ Tumor size } \\
\hline$\leq 2 \mathrm{~cm}$ & 48 & 37.21 & 229 & 39.69 & 0.792 \\
\hline$>2 \mathrm{~cm}$ & 66 & 51.16 & 298 & 51.65 & \\
\hline Not available & 15 & 11.63 & 50 & 8.67 & \\
\hline \multicolumn{6}{|c|}{ Lymph node involvement } \\
\hline Negative & 84 & 65.12 & 280 & 48.53 & 0.001 \\
\hline Positive & 45 & 34.88 & 290 & 50.26 & \\
\hline Not available & 0 & 0 & 7 & 1.21 & \\
\hline \multicolumn{6}{|l|}{ Family history } \\
\hline Yes & 8 & 6.20 & 30 & 5.20 & 0.599 \\
\hline No & 110 & 85.27 & 512 & 88.73 & \\
\hline Not available & 11 & 8.53 & 35 & 6.07 & \\
\hline
\end{tabular}

${ }^{a}$ Chi-square test for age at diagnosis, tumor size, lymph node involvement, and family history distribution between triple negative and non-triple negative breast cancer patients; nonparametric rank test for distribution of age at menarche and childbearing between triple negative and non-triple negative breast cancer patients. 
Table 4 Risk of subtype-specific breast cancer in relation to family history of breast cancer compared with benign breast disease control

\begin{tabular}{|c|c|c|c|c|}
\hline Variable & OR $(95 \% \mathrm{Cl})^{\mathrm{a}}$ & $P^{\mathrm{a}}$ & OR $(95 \% \mathrm{Cl})^{\mathrm{b}}$ & $P^{b}$ \\
\hline \multicolumn{5}{|l|}{ Pathology } \\
\hline DCIS & 1.27 (0.36 to 4.46$)$ & 0.704 & 1.30 (0.38 to 4.43$)$ & 0.679 \\
\hline Invasive cancer & $2.22(1.32$ to 3.75$)$ & 0.003 & 2.26 (1.36 to 3.75$)$ & 0.002 \\
\hline \multicolumn{5}{|l|}{ Tumor size $^{c}$} \\
\hline$\leq 2 \mathrm{~cm}$ & 1.87 (0.92 to 3.80) & 0.084 & 1.94 (0.97 to 3.87) & 0.061 \\
\hline$>2 \mathrm{~cm}$ & 2.29 (1.22 to 4.29$)$ & 0.010 & 2.34 (1.28 to 4.30$)$ & 0.006 \\
\hline \multicolumn{5}{|c|}{ Lymph node involvement ${ }^{c}$} \\
\hline Negative & $2.60(1.42$ to 4.75$)$ & 0.002 & 2.56 (1.43 to 4.57$)$ & 0.001 \\
\hline Positive & 2.07 (1.05 to 4.08$)$ & 0.036 & 2.14 (1.10 to 4.15$)$ & 0.025 \\
\hline \multicolumn{5}{|c|}{ Hormone receptor status ${ }^{c}$} \\
\hline Negative & 3.05 (1.45 to 6.41$)$ & 0.003 & $2.76(1.35$ to 5.64$)$ & 0.005 \\
\hline Positive & 2.09 (1.16 to 3.78$)$ & 0.014 & 2.19 (1.23 to 3.89$)$ & 0.008 \\
\hline \multicolumn{5}{|l|}{ Molecular subtype ${ }^{c}$} \\
\hline Triple negative & 3.35 (1.43 to 7.88$)$ & 0.005 & 3.17 (1.38 to 7.28$)$ & 0.007 \\
\hline Non-triple negative & 2.14 (1.21 to 3.80$)$ & 0.009 & 2.20 (1.27 to 3.82 ) & 0.005 \\
\hline
\end{tabular}

of breast cancer $>2 \mathrm{~cm}(\mathrm{OR}=2.29,95 \% \mathrm{CI}=1.22$ to $4.29, P=0.010)$, and borderline significantly associated with an increased risk of breast cancer $\leq 2 \mathrm{~cm}(\mathrm{OR}=$ $1.87,95 \% \mathrm{CI}=0.92$ to $3.80, P=0.084)$. Furthermore, family history was significantly associated with an increased risk of breast cancer with negative $(\mathrm{OR}=2.60$, $95 \% \mathrm{CI}=1.42$ to $4.75, P=0.002)$ and positive lymph nodes $(\mathrm{OR}=2.07,95 \% \mathrm{CI}=1.05$ to $4.08, P=0.036)$. When breast cancers were divided into two groups according to hormone receptor status, family history was associated with an increased risk of both hormone receptor negative $(\mathrm{OR}=3.05,95 \% \mathrm{CI}=1.45$ to 6.41 , $P=0.003)$ and positive breast cancer ( $\mathrm{OR}=2.09,95 \%$ $\mathrm{CI}=1.16$ to $3.78, P=0.014)$. Importantly, having a family history of breast cancer was associated with an increased risk of triple negative breast cancer $(\mathrm{OR}=3.35$, $95 \% \mathrm{CI}=1.43$ to $7.88, P=0.005)$ with a magnitude of association similar to that for non-triple negative breast cancer $(\mathrm{OR}=2.14,95 \% \mathrm{CI}=1.21$ to $3.80, P=0.009)$. When multivariate analyses were performed without considering age at diagnosis, the results were similar to those given in Table 4.

\section{Discussion}

This case-control study suggests that a family history of breast cancer is associated with an increased breast cancer risk; this is consistent with prior studies [7-12]. Importantly, the proportions of patients with a family history in the triple negative and non-triple negative groups were not significantly different in Han Chinese people. A family history of breast cancer was associated with an increased risk of triple negative breast cancer, with a magnitude of association similar to that for nontriple negative breast cancer in multivariate analyses. Furthermore, family history was not significantly associated with an increased risk of DCIS in our study.

Consistent with previous studies [3,7-12], our data indicate a 2.11-fold increased breast cancer risk in women with any-degree family history. However, subjects with benign breast disease, which is an important risk factor for subsequent breast cancer [8], were applied as controls. Furthermore, the proportion of subjects with a family history in the control group was $3.2 \%$, while this proportion is about $1 \%$ in the general population in China [1]. So, the relationship between family history and risk of breast cancer may be underestimated in this case-control study.

In this study, triple negative tumors were observed among $18.3 \%$ of patients, a rate comparable to our previous study [26] and another Chinese study [28]. A lower proportion of lymph node involvement was observed in triple negative tumors in this study, which was also comparable to previous studies [26,28,29]. Even with less lymph node involvement, triple negative breast cancers still show poor prognosis. Thus, it is important to explore the risk of this subtype of tumors. In this study, we found a 3.55 -fold increased risk of triple negative breast cancer in women with a family history, which was similar to that for non-triple negative breast cancer. Further cohort studies with large sample size are needed to confirm our findings.

Most previous studies are focused on the relationship between family history and risk of invasive breast cancers. However, DCIS cannot be ignored, although DCIS shows encouraging prognosis [30]. A long-term followup study [30] found that the rate of local recurrence was high, and $48 \%$ of these recurrences were invasive. Previous studies [21-25] suggest that family history is a risk factor of DCIS. However, no relationship between family history and risk of DCIS was observed in Han Chinese people. With the exception of this racial or ethnic difference, our results might also be influenced by small sample size and benign breast disease controls. The relationship between family history and risk of DCIS should be investigated in Asian populations to confirm our findings.

Several limitations still exist in our study. First, subjects with benign breast disease were selected as controls, so the association between family history and breast cancer risk may have been underestimated. Second, the sample size of DCIS in our study was relatively small; future studies with large sample sizes are needed to explore the relationship between family history and risk of DCIS. Third, owing to the nature of this case-control study, 
future large cohort studies should be conducted to explore these relationships.

\section{Conclusions}

In conclusion, our results indicate that a family history of breast cancer is associated with an increased risk of triple negative breast cancer with a magnitude of association similar to that for non-triple negative breast cancer. Furthermore, family history was not significantly associated with an increased risk of DCIS in our study. Future cohort studies with large sample size are still needed to explore these relationships.

\section{Abbreviations}

Cl: Confidence interval; DCIS: Ductal carcinoma in situ; ER: Estrogen receptor; H \& E: Hematoxylin and eosin; OR: Odds ratio; PR: Progesterone receptor; SD: Standard deviation.

\section{Competing interests}

The authors declare that they have no competing interests.

\section{Authors' contributions}

SW contributed to the conception and design of the study, the analysis, and interpretation of data, the revision of the article, and final approval of the version to be submitted. $K X, W Z$, and HP participated in the design of the study, performed the statistical analysis, and drafted and revised the article. KX, WZ, HP, XiuL, ML, JinX, LC, JiaX, SC, XiaL, QD, and LL performed the study. All authors read and approved the final version of the manuscript.

\section{Acknowledgements}

This work was supported in part by the National Natural Science Foundation of China $(81071753,81172505,81202077$, and 81272916), the Natural Science Foundation of Jiangsu Province (BK2010581, BK2011853, and BK2011855), the Program for Development of Innovative Research Team in the First Affiliated Hospital of NJMU (IRT-008) and a project funded by the Priority Academic Program Development of Jiangsu Higher Education Institutions (PAPD).

\section{Author details}

'Department of Breast Surgery, The First Affiliated Hospital with Nanjing Medical University, 300 Guangzhou Road, Nanjing 210029, China. ${ }^{2}$ Department of Breast Surgery, The Affiliated Jiangyin Hospital of Southeast University Medical College, 163 Shoushan Road, Jiangyin 214400, China.

Received: 13 March 2013 Accepted: 22 September 2013 Published: 1 October 2013

\section{References}

1. Yu ZG, Jia CX, Liu LY, Geng CZ, Tang JH, Zhang J, Zhang Q, Li YY, Ma ZB: The prevalence and correlates of breast cancer among women in Eastern China. PLoS One 2012, 7(6):e37784.

2. Kamangar F, Dores GM, Anderson WF: Patterns of cancer incidence, mortality, and prevalence across five continents: defining priorities to reduce cancer disparities in different geographic regions of the world. J Clin Oncol 2006, 24(14):2137-2150.

3. Phipps Al, Buist DS, Malone KE, Barlow WE, Porter PL, Kerlikowske K, Li Cl: Family history of breast cancer in first-degree relatives and triplenegative breast cancer risk. Breast Cancer Res Treat 2011, 126(3):671-678.

4. Nielsen TO, Hsu FD, Jensen K, Cheang M, Karaca G, Hu Z, HernandezBoussard T, Livasy C, Cowan D, Dressler L, Akslen LA, Ragaz J, Gown AM, Gilks CB, van de Rijn M, Perou CM: Immunohistochemical and clinical characterization of the basal-like subtype of invasive breast carcinoma. Clin Cancer Res 2004, 10(16):5367-5374.

5. Dent R, Trudeau M, Pritchard Kl, Hanna WM, Kahn HK, Sawka CA, Lickley LA, Rawlinson E, Sun P, Narod SA: Triple-negative breast cancer: clinical features and patterns of recurrence. Clin Cancer Res 2007, 13(15 Pt 1):4429-4434

6. Rodriguez-Pinilla SM, Sarrio D, Honrado E, Hardisson D, Calero F, Benitez J, Palacios J: Prognostic significance of basal-like phenotype and fascin expression in node-negative invasive breast carcinomas. Clin Cancer Res 2006, 12(5):1533-1539.

7. Ready K, Arun B: Clinical assessment of breast cancer risk based on family history. J Natl Compr Canc Netw 2010, 8(10):1148-1155.

8. Zhou WB, Xue DQ, Liu XA, Ding Q, Wang S: The influence of family history and histological stratification on breast cancer risk in women with benign breast disease: a meta-analysis. J Cancer Res Clin Oncol 2011, 137(7):1053-1060.

9. Collaborative Group on Hormonal Factors in Breast Cancer: Familial breast cancer: collaborative reanalysis of individual data from 52 epidemiological studies including 58,209 women with breast cancer and 101,986 women without the disease. Lancet 2001, 358(9291):1389-1399.

10. Pharoah PD, Day NE, Duffy S, Easton DF, Ponder BA: Family history and the risk of breast cancer: a systematic review and meta-analysis. Int J Cancer 1997, 71(5):800-809.

11. Anderson $\mathrm{H}$, Bladstrom $\mathrm{A}$, Olsson $\mathrm{H}$, Moller TR: Familial breast and ovarian cancer: a Swedish population-based register study. Am J Epidemiol 2000 152(12):1154-1163.

12. Negri E, Braga C, La Vecchia C, Franceschi S, Parazzini F: Family history of cancer and risk of breast cancer. Int J Cancer 1997, 72(5):735-738.

13. Millikan RC, Newman B, Tse C-K, Moorman PG, Conway K, Smith LV, Labbok MH, Geradts J, Bensen JT, Jackson S, Nyante S, Livasy C, Carey L, Earp HS, Perou CM: Epidemiology of basal-like breast cancer. Breast Cancer Res Treat 2008, 109(1):123-139.

14. Yang XR, Sherman ME, Rimm DL, Lissowska J, Brinton LA, Peplonska B, Hewitt SM, Anderson WF, Szeszenia-Dabrowska N, Bardin-Mikolajczak A, Zatonski W, Cartun R, Mandich D, Rymkiewicz G, Ligaj M, Lukaszek S, Kordek $\mathrm{R}$, García-Closas M: Differences in risk factors for breast cancer molecular subtypes in a population-based study. Cancer Epidemiol Biomarkers Prev 2007, 16(3):439-443.

15. Jiang $X$, Castelao JE, Chavez-Uribe E, Fernandez Rodriguez B, Celeiro Muñoz C, Redondo CM, Peña Fernandez M, Novo Dominguez A, Pereira CD Martínez ME, García-Caballero T, Fraga Rodriguez M, Antúnez J, Carracedo A, Forteza-Vila J, Gago-Dominguez M: Family history and breast cancer hormone receptor status in a Spanish cohort. PLoS One 2012, 7(1):e29459.

16. Li Cl, Malone KE, Daling JR: Differences in breast cancer stage, treatment, and survival by race and ethnicity. Arch Intern Med 2003, 163(1):49-56.

17. Shavers VL, Harlan LC, Stevens $J$ : Racial/ethnic variation in clinical presentation, treatment, and survival among breast cancer patients under age 35. Cancer 2003, 97(1):134-147.

18. Chu KC, Anderson WF: Rates for breast cancer characteristics by estrogen and progesterone receptor status in the major racial/ethnic groups. Breast Cancer Res Treat 2002, 74(3):199-211.

19. Chu KC, Anderson WF, Fritz A, Ries LA, Brawley OW: Frequency distributions of breast cancer characteristics classified by estrogen receptor and progesterone receptor status for eight racial/ethnic groups. Cancer 2001, 92(1):37-45

20. Carey LA, Perou CM, Livasy CA, Dressler LG, Cowan D, Conway K, Karaca G, Troester MA, Tse CK, Edmiston S, Deming SL, Geradts J, Cheang MC, Nielsen TO, Moorman PG, Earp HS, Millikan RC: Race, breast cancer subtypes, and survival in the Carolina Breast Cancer Study. JAMA 2006, 295(21):2492-2502.

21. Virnig BA, Wang SY, Shamilyan T, Kane RL, Tuttle TM: Ductal carcinoma in situ: risk factors and impact of screening. J Natl Cancer Inst Monogr 2010, 2010(41):113-116.

22. Claus EB, Stowe M, Carter D: Breast carcinoma in situ: risk factors and screening patterns. J Natl Cancer Inst 2001, 93(23):1811-1817.

23. Claus EB, Stowe M, Carter D: Family history of breast and ovarian cancer and the risk of breast carcinoma in situ. Breast Cancer Res Treat 2003, 78(1):7-15

24. Trentham-Dietz A, Newcomb PA, Storer BE, Remington PL: Risk factors for carcinoma in situ of the breast. Cancer Epidemiol Biomarkers Prev 2000, 9(7):697-703.

25. Kerlikowske K, Barclay J, Grady D, Sickles EA, Ernster V: Comparison of risk factors for ductal carcinoma in situ and invasive breast cancer. J Natl Cancer Inst 1997, 89(1):76-82.

26. Zhou W, He Z, Xue J, Wang M, Zha X, Ling L, Chen L, Wang S, Liu X: Molecular subtype classification is a determinant of non-sentinel lymph node metastasis in breast cancer patients with positive sentinel lymph nodes. PLoS One 2012, 7(4):e35881. 
27. Wolff AC, Hammond ME, Schwartz JN, Hagerty KL, Allred DC, Cote RJ, Dowsett M, Fitzgibbons PL, Hanna WM, Langer A, McShane LM, Paik S, Pegram MD, Perez EA, Press MF, Rhodes A, Sturgeon C, Taube SE, Tubbs R, Vance GH, van de Vijver M, Wheeler TM, Hayes DF, American Society of Clinical Oncology, College of American Pathologists: American Society of Clinical Oncology/College of American Pathologists guideline recommendations for human epidermal growth factor receptor 2 testing in breast cancer. J Clin Oncol 2007, 25(1):118-145.

28. Yin WJ, Lu JS, Di GH, Lin YP, Zhou LH, Liu GY, Wu J, Shen KW, Han QX, Shen ZZ, Shao ZM: Clinicopathological features of the triple-negative tumors in Chinese breast cancer patients. Breast Cancer Res Treat 2009, 115(2):325-333.

29. Reyal F, Rouzier R, Depont-Hazelzet B, Bollet MA, Pierga JY, Alran S, Salmon RJ, Fourchotte V, Vincent-Salomon A, Sastre-Garau X, Antoine M, Uzan S, Sigal-Zafrani B, De Rycke Y: The molecular subtype classification is a determinant of sentinel node positivity in early breast carcinoma. PLoS One 2011, 6(5):e20297.

30. Wallis MG, Clements K, Kearins O, Ball G, Macartney J, Lawrence GM: The effect of DCIS grade on rate, type and time to recurrence after 15 years of follow-up of screen-detected DCIS. Br J Cancer 2012, 106(10):1611-1617.

doi:10.1186/1477-7819-11-248

Cite this article as: Zhou et al: Family history and risk of ductal carcinoma in situ and triple negative breast cancer in a Han Chinese population: a case-control study. World Journal of Surgical Oncology 2013 11:248.

\section{Submit your next manuscript to BioMed Central and take full advantage of:}

- Convenient online submission

- Thorough peer review

- No space constraints or color figure charges

- Immediate publication on acceptance

- Inclusion in PubMed, CAS, Scopus and Google Scholar

- Research which is freely available for redistribution 